て, 注射した ATP が直接肝細胞作用しているのか， または全身的作用することによるものか明らかでな い。

\section{3. 四塩化炭素中罍に関する臨床的研究}

牛尾耕一，譀訪広一郎，上原宏一郎，竹内正 (関東学琰病踪内科) 我々は某ダイアモンド加工工場彷業員23名について, 臨床的研究を行なった。自覚症は脰気を全例化認め，之 くに算期の夕刻汇著るしい。血液学的検查，腎機能，消 化器系とも比異常を認めなからたが，肝穖能梌查に执い ては，異常值を示するのを大多数汇認好，らち2 名につ いては，肝生検を实施したので，これらの成績について 報告したい。

\section{4. ダイナ゙マイト製造工場における} ニトログリコール中囊の調查

山口正義, 坂部弘之, 矮田、昭, 吉川 博, 松下移鶴, 松村芳美, 橋爪 稳 (労衛研)

近来，ダイナマイト製造工程に执いて，ニトログリセ リンの谏結防止のため，ニトロ、グリコールが混入される。 ようになつたが，その混入率の增加とともに，若干の死 亡者を含它，中毒患者が発生するにいたったので，学働 省の依頼により，緊急の調查を行なったが，その綪果を 報告したい。中毒症状として最も重要なるのは, ニトロ グリコールヘの嚗露を中止して後, 1〜3日後, 主とし て早朝出現する, 軽度のものから死亡に生で至る规心症 に似た発作である。つぎに頭痛，胸部王迫感，此気，心雲 亢進, 手足のしびれ感, 僚急感, アルュール柯性の低下 等の自覚症状が訴光られている。これらの自覚症状のあ るものは，作業代つきじめ，また怢後の作業，ま， たは高濃度のものに曝露した時等に訴光られている。

血压は全般に最高血圧の低下を認めたが，これが，地 域性のものかどうかな捈討中である。休日あけの作業 日の作業前後の血王伔ついて検討したが，統一的な結論 をひき出すことはできなかつた。作業場内に打㐌るニト ログリコールの浱度については, 爆発を考慮して, 手迴 しミゼットインピンジャーにより，エタノール中に捕集 し, phenoldisulfonic acid を呈色試晁として用いる, 硫酸イオンの一般的な定量法を若干改変して，䇥量を行 なった。従ってニトログリセン並びにニトログリコール の両者を測定することになるが後者の前者に比して圧倒 的に大きい蒸気压を考虑すると, 気相では後者が添とん ぞであるうと考觉られる。また環境中の他の硝酸塩また
は硝酸エステルも考慮に入れることが必要な場合もある が，本法で㵋定した結果は大体 $0.30 \sim 0.89 \mathrm{ppm}(二$. ログリコールとして) であった。

\section{5. ガスクロマトグラフによる}

空気中アクリロニトリルの分離定量法

橋本和夫 (大阪府立公衛研)

空氮中アリリロニトリルの定量には，すでにいくつか の方法が用いられている。演者はガスクロマトグラフを 用いて，本物質の怒限度之されている $20 \mathrm{ppm}$ の低濃度 までを, 他のニトリル化合物, 青酸などと分離して定量 する方法を検討したので報告する。ガスクロマトグラフ はコタキ䈀 GD-3 型(熱伝導形)を用いた。キャリヤー ガスは $\mathrm{He}$ ，固定相液体にはオキシジプロピオニトリル (ODPN) または快リエチレングリコール (DEG) を採 用した。ODPN はニトりル化合物や青酸の分離に適し， PEG は水分含有量の多い空気で水分上の分踓汇有効で あることがわかった。いずれの場合もアクリロニトリル の濃度の低いものには予じめ濃縮方法を䈋じた。このた めには内容約 $3 \mathrm{cc} の \mathrm{U}$ 字管に PEG を含む担体 $1 \mathrm{~g}$ 充塡し，管全体をドライアイス・アセトン中につけ，被 検空気を通して濃縮補集する方法を用いた。この際，空 気中水分が㠜結して管を閉塞するので，予じめ除湿を行 なったが，この目的には塩化カルシウムが最も適してい た。被検空気 $5 l$ を濃縮することにより，20 ppm まで のアクリロニトリルを定量誤差 $5 \%$ 以内で分析できるこ とがわから龙。

\section{6. 尿吅硫酸の定量法：}

\section{Thorium-amaranth 法の検討}

渡辺 弘, 細川 汀, 村山七サ子, 山岡茂夫 （大阪市立衛研）

尿中エーテル硫酸比の測定汇は, 従来, benzidine 法 が用いられてきたが, 種々の不便な点もあり, 最近, 比 色法がいくつか報告されている。 Lambert らは thorium-amaranth chelate が硫酸イオンと反応し, その 浱度に比例して色素を遊誰させることを利用して，河川 の硫酸定量法を発表しているが，私どもはこの方法を尿 中硫酸の定量に用いるため, 検討を行なった。

この方法によると, 硫酸涯加尿で標準曲線は Beer の 法則を充たし，極大吸収波長は $520 \sim 525 \mathrm{~m} \mu$ である。 しかし実測値は, benzidine 法化比して，1.5 2.5 倍 の值を示し，他の物質の妨害を受好る。すなるち，thorium-amaranth は硫酸と選択的に反忘するものではな 